УДК 347.254

DOI https://doi.org/10.32849/2663-5313/2019.6.07

\title{
Вікторія Породько,
}

канд. юрид. наук, дочент,

доцент кафедри цивільно-правових дисциплін

Національної академії Служби безпеки Украйни

\section{ПІДСТАВИ ВИСЕЛЕННЯ ЗІ СЛУЖБОВОГО ЖИТЛА В КОНТЕКСТІ ВИСНОВКІВ ВЕЛИКОЇ ПАЛАТИ ВЕРХОВНОГО СУДУ}

У статті з урахуванням позииї Великої Палати Верховного Суду та внаслідок порівняння норм начіонального законодавства Украӥни й міжнародно-правових актів розкриваються та аналізуються зміст підстав для виселення зі службових житлових приміщень, механізм їх обгрунтування, а також формуються пропозицї щодо законодавчого врегулювання правовідносин у цій сфері.

Ключові слова: службове житло, виселення зі службового житла, підстави для виселення, володіння нерухомим майном, втручання у право особи на повагу до житла.

Постановка проблеми. Створення, збереження й організація ефективного функціонування фонду службового житла в умовах зменшення частки державного сектору економіки країни не лише є вагомим засобом забезпечення нормальної діяльності підприємств, установ, організацій і державного апарату, а й сприяють реалізації конституційного права громадян на житло. Інститут службового житла дає змогу здійснювати належне кадрове наповнення виробничої сфери, військових формувань, правоохоронних органів, судів, залучаючи до трудових чи службових відносин кращих спеціалістів, здатних кваліфіковано виконувати свої обов'язки та реалізовувати повноваження. Водночас він дає можливість особам, які перебувають на державному забезпеченні житлом, мати гідні житлові умови на період до отримання помешкання для постійного проживання.

Раціональне використання службового житла значною мірою залежить від дотримання встановленого житловим законодавством порядку надання службових житлових приміщень, користування ними та виселення з них у разі втрати підстав для проживання.

Судова практика останніх років у справах цієї категорії свідчить про те, що саме під час вирішення спорів про виселення виникає найбільше протиріч, пов'язаних, як правило, 3 визначенням та обгрунтуванням підстав для виселення зі службового житла й дотриманням процедури розірвання відносин між власником службового житлового приміщення та наймачем.

До питання правового регулювання інституту службового житла в працях зверталися В.Я. Бондар, М.В. Іванчук, Г.І. Кова- ленко, А.В. Мінаєв, А.Ю. Олійник, С.О. Сліпченко, М.О. Шишлюк, I.І. Штангрет та інші правознавці. Водночас науковці здебільшого зосереджуються лише на загальних положеннях житлового законодавства, оминаючи увагою проблему підстав виселення зі службового житла.

Метою статті є з'ясування на основі дослідження положень чинного законодавства з урахуванням висновків Великої Палати Верховного Суду (далі - ВПВС), викладених у Постанові від 4 липня 2018 року у справі № 653/1096/16ц про визнання осіб такими, що втратили право на проживання у службовій квартирі, їх виселення та зняття з реєстрації [1], сутності підстав виселення зі службового житла й визначення їх складників, що підлягають закріпленню в житловому законодавстві України.

Виклад основного матеріалу. Можливість отримання особою службового житла прямо пов'язана з її перебуванням у трудових відносинах із підприємством, установою, організацією та наявною у зв'язку з цим потребою проживання за місцем роботи або поблизу нього (ч. 1 ст. 118 Житлового кодексу УРСР (далі - ЖК)) [2].

Незважаючи на те що за чинним законодавством України службове житло не належить до житлових приміщень із фондів житла для тимчасового проживання, його використання не має постійного характеру, оскільки обмежується часом перебування особи, якій воно було надане, у трудових правовідносинах із роботодавцем. Констатуючи цю правову дефініцію [1, п. 61], ВПВС слушно зауважила, що той, хто користується 
службовим житловим приміщенням, усвідомлює свій обов'язок щодо його звільнення після припинення трудових правовідносин із підприємством, установою, організацією, яка $€$ його власником, а формулювання приписів ЖК із цього питання є досить чітким, щоб їх розуміти [1, п. п. 31,60$]$.

В основу тимчасовості проживання в службовому житловому приміщенні покладено право власності на нього як на нерухоме майно, що належить державі в особі уповноважених підприємства чи установи або громадській чи кооперативній організації. Пройшовши процедуру включення житлового приміщення до службових, визначену ч. 1 ст. 118 ЖК [2], і зареєструвавши право на нього як на об'єкт нерухомості відповідно до ч. 4 ст. 334 Цивільного кодексу України (далі - ЦК) [3] у державному реєстрі, вони стають його власником із повноцінним правом володіння, користування й розпорядження, закріпленим у ч. 1 ст. 317 ЦК [3].

Особа, яка в установленому законом порядку отримує службове житло для проживання, набуває право користування таким житловим приміщенням на підставі спеціального ордера, виданого виконавчим комітетом місцевої ради. Можливість розпоряджатися таким житлом на свій розсуд для наймача житлове законодавство, по суті, виключає, встановлюючи обмеження на бронювання службових житлових приміщень, їх обмін, зміну договору найму. Що ж до права володіння, то в цивілістичній науці його традиційно найчастіше тісно пов'язують із правом користування житлом, розтлумачуючи як можливість постійного та безперешкодного знаходження в житловому приміщенні та реально контролювати його стан [4, с. 42]. У зв'язку з цим правознавцями висловлювалася думка, що, оскільки наймач службового житла вважається особою, яка фізично контролює об'єкт проживання і $є$ його «нинішнім» володільцем, його виселення має відбуватися в порядку віндикації, тобто витребування майна 3 чужого незаконного володіння в межах передбачених ч. 11 ст. 257 ЦК строків позовної давності, недотримання яких є підставою для втрати права власності [5].

ВПВС у п. 91 Постанови відійшла від усталеного бачення, зазначивши, що наймач житла має лише право тимчасового володіння (defentio) ним, а саме право володіння (possessio) житлом залишається в його власникай визнаєтьсязаним навіть тоді, коли інша особа використовує таке майно протиправно.

Зазначене твердження відповідає висновкам судової інстанції щодо виду позову про виселення зі службового житла, і хоча в чинному цивільному та житловому законодавстві не наводиться подібна диференціація видів володіння, наука цивільного права розрізняє фактичне та юридичне володіння майном. Водночас рішення ВПВС із цього питання не позбавлене певних суперечностей, оскільки в низці попередніх висновків, зроблених у цій же Постанові, підкреслюється, що володільцем службового житла залишається саме власник останнього, а 3 наймачем пов'язують право користування [1, п. п. 31, 51].

Саме на відносинах власності грунтується висновок ВПВС [1, п. 52] щодо непоширення на позови про виселення зі службових житлових приміщень строків позовної давності. Проаналізувавши передбачені цивільним законодавством способи захисту речових прав, зокрема витребування майна 3 чужого незаконного володіння [3, ст. 387] та усунення перешкод у здійсненні права користування й розпорядження майном [3, ст. 391], і дослідивши характер відносин, які виникають у наймодавця та наймача 3 приводу використання службового житла, судова інстанція логічно визначила, що такі позови належать до негаторних, тобто позовів про усунення перешкод у здійсненні права користування та розпорядження майном, до яких позовна давність не застосовується.

Отже, $з$ моменту припинення трудових відносин із наймодавцем, який є власником службового житла, для наймача перестають існувати правові підстави користування ним, що, по суті, робить подальше користування незаконним і призводить до виникнення в підприємства, установи, організації, які надавали службове житлове приміщення для проживання, права на звернення до суду 3 позовом про виселення в будь-який час, поки триває це правопорушення.

Зазначене судове рішення відіграє важливу роль і у визнанні права власника службового житла на виселення 3 нього наймача, у якого наявні передбачені ст. 125 ЖК [2] обставини, що перешкоджають виселенню без надання іншого житлового приміщення, після того, як ці обставини припиняють існування з об'єктивних причин. На практиці строки, протягом яких це відбувається, нерідко перевищують строки позовної давності, встановлені законодавством, що породжувало спори про набувальну давність.

Відповідно до положень ст. 124 ЖК робітники і службовці, які припинили трудові відносини з підприємством, установою, організацією, підлягають виселенню зі службового житлового приміщення 3 усіма особами, які з ними проживають, без надання іншого житлового приміщення [2]. Тим 
самим єдиною підставою для виселення зі службового житла законодавство України визначає припинення трудових (службових) відносин наймача 3 власником службового житлового приміщення. Зауважимо, що в контексті цієї статті не розглядаються питання виселення зі службового житла на підставах, загальних для всіх видів житла (осіб, які самовільно зайняли житлове приміщення; проживають у будинках, що загрожують обвалом, підлягають знесенню або переобладнанню в нежитлові; осіб, які систематично руйнують чи псують житлове приміщення або використовують його не за призначенням, тощо).

ВПВС, аналізуючи підстави для виселення зі службового житла, застосувала як джерело права Конвенцію про захист прав людини i основоположних свобод (далі - Конвенція), протоколи до неї, згоду на обов'язковість яких надано Верховною Радою України, і практику Свропейського суду з прав людини (далі - ССПЛ).

У статті 8 Конвенції передбачено, що кожен має право на повагу до свого приватного й сімейного життя і свого житла, а органи державної влади не можуть втручатися в здійснення цього права, за винятком випадків, коли втручання здійснюється згідно із законом і $€$ необхідним у демократичному суспільстві в інтересах національної та громадської безпеки чи економічного добробуту країни, для запобігання заворушенням чи злочинам, для захисту здоров'я чи моралі або для захисту прав і свобод інших осіб [6]. На особливу важливість цих прав для особистості людини, її усталеного й безпечного місця в суспільстві наголосив і ЄСПЛ у рішенні у справі «Коннорз проти Сполученого Королівства» [7].

Із цінностей, перелічених у наведеній міжнародно-правовій нормі, вочевидь, виселення особи з житлового приміщення посягає на їі право на повагу до свого житла. Це підтверджується й посиланням ВПВС на рішення ССПЛ, за яким утрата житла визнається найбільш крайньою формою втручання у право на повагу до нього [8].

Конституція України, як Основний Закон, та житлове й цивільне законодавство, що регулює житлово-правові відносини в нашій країні, не містять такої юридичної конструкції, як «право на повагу до житла».

Конституція України в ст. 47 [9] гарантує, а ЖК в ст. 1 [2] закріплює право громадян на житло, за яким держава створює для кожного умови побудови чи придбання житла у власність або взяття його в оренду, а громадянам, які потребують соціального захисту, держава й органи місцевого самоврядування надають житло безоплатно або за доступну для них плату відповідно до закону. Зазначене право за своїм змістом належить до майнових прав.

Водночас Основний Закон України гарантує недоторканність житла [9, ст. 30], закріплюючи це право забороною на проникнення до житла, проведення в ньому огляду чи обшуку не інакше як за вмотивованим рішенням суду. Право на недоторканність житла встановлює й цивільне законодавство України, класифікуючи його як особисте немайнове право, що забезпечує соціальне буття фізичної особи. Саме ст. 311 ЦК в ч. 4 вказує на виселення або іншим чином примусове позбавлення житла фізичної особи як на обмеження права на недоторканність житла у випадках, установлених законом [3].

Отже, з європейським правом на повагу до житла в українському законодавстві співвідноситься право на недоторканність житла, обмеженням якого є виселення 3 помешкання. Тому не відповідає висновкам, зробленим самою ж ВПВС, уживання у п. п. 58, 65 Постанови конструкції «право на житло» [1], особливо коли йдеться про посилання на практику ЄСПЛ, який чітко застосовує термінологію «право на повагу до житла», що не $€$ ідентичною.

Попри те що в Україні виселення зі службового житла закон чітко пов'язує 3 припиненням трудових або службових відносин наймача з власником цього житла, ст. $8 \mathrm{Koн}^{-}$ венції визнає правомірним втручання органів державної влади у право особи на повагу до свого приватного й сімейного життя та свого житла, якщо воно не лише здійснюється у зв'язку із законом, але є необхідним в інтересах національної та громадської безпеки чи економічного добробуту країни, для запобігання заворушенням чи злочинам, для захисту здоров’я чи моралі або для захисту прав і свобод інших осіб [6].

Конституція України допускає обмеження недоторканності житла в невідкладних випадках, пов'язаних з урятуванням життя людей і майна чи з безпосереднім переслідуванням осіб, які підозрюються в учиненні злочину [9, ч. 2 ст. 30], а недоторканності особистого життя - в інтересах національної безпеки, економічного добробуту і прав людини [9, ч. 2 ст. 32].

Подібне співвідношення не свідчить про узгодженість підходів до визначення мети виселення фізичної особи із житлового приміщення за міжнародним та українським законодавством, що, безумовно, ускладнює характеристику підстав для обмеження права. ЖК закріплює охорону житлових прав, за винятком їх здійснення в суперечності з призначенням чи з порушенням прав інших 
громадян або прав державних і громадських організацій [2, ч. 5 ст. 9]. Такий підхід більш чітко відображає цінності, яким завдається шкода внаслідок незаконного використання службового житла.

Аналізуючи легітимну (у розумінні ст. 8 Конвенції) мету виселення особи зі службового житла, ВПВС зазначила, що після припинення іï трудових відносин із роботодавцем, який надав це житло, вона повинна повернути службове приміщення, щоб у ньому мали можливість проживати інші працівники [1, п. п. 61, 62]. Звідси мета виселення полягає саме в забезпеченні прав інших громадян і прав державних і громадських організацій, які є власниками службових житлових приміщень або за якими останні закріплені на праві оперативного управління.

Важко погодитися 3 підтримкою ВПВС позиції ССПЛ щодо визначення мети виселення у справі «Каракуця проти України» [10], за якою втручання у право на повагу до житла колишнього військовослужбовця та членів його сім'ї, які були виселені з кімнати в гуртожитку після припинення служби в Міністерстві оборони України, переслідувало, окрім захисту прав інших військовослужбовців і працівників, які потребували житло у зв'язку зі службою чи роботою, ще й мету захисту інтересів економічного добробуту країни. Вплив правомірного виселення однієї сім'ї із житлового приміщення в гуртожитку на економічний добробут країни $є$ вкрай сумнівним. До того ж у цьому конкретному випадку незаконне використання службового житла військового відомства скоріше зачіпає інтереси національної безпеки, куди належить сфера оборони, а не економічного потенціалу.

Необхідність застосування до фізичної особи такого заходу, як примусове виселення із житла, у демократичному суспільстві також визначається співмірністю втручання в її право на недоторканність житла меті, яка при цьому досягається. Службове житлове приміщення, що звільняється в результаті примусового виселення осіб, які, згідно із законом, утратили право користування ним, має бути потрібне власнику для використання за призначенням на момент виселення й не може простоювати тривалий час без заселення, тоді як колишній наймач залишиться без житла. Виселення особи зі службового житлового приміщення без надання іншого житла має також зумовлюватись відсутністю обставин, які його унеможливлюють, що передбачені ст. 125 ЖК [2].

Отже, до складників підстави для виселення зі службових житлових приміщень без надання іншого житла можна зарахувати:
- припинення трудових або службових відносин із державним органом, підприємством, установою, організацією, які є власником службового житлового приміщення або за якими це майно закріплене на праві оперативного управління;

- відсутність визначених ст. 125 ЖК обставин, що унеможливлюють виселення безприпинення трудовихнадання іншого житла;

- необхідність забезпечення прав інших громадян на отримання службового житла та прав його власника на використання за призначенням як мету виселення;

- неможливість досягнення зазначеної мети іншим шляхом, ніж обмеженням права фізичної особи на недоторканність житла.

Важливого значення в практичній площині застосування підстави для виселення зі службового житла в контексті висновків ВПВС набуває її обгрунтування. Воно стає обов'язковим елементом судового дослідження в конкретних спорах, що впливає наприпинення трудовихсутність прийнятих рішень.

Статус конкретного помешкання як службового повинен бути визначений рішенням виконавчого органу районної, міської, районної в місті ради про включення його до переліку службових приміщень. Він закріплює призначення останнього, а також особливий режим надання, використання й виселення 3 нього наймача та членів його сім'ї. Право власності роботодавця на службове житло має підтверджуватися фактом його державної реєстрації в установленому законом порядку. У рішенні про розподіл службового житла закріплюються дані про виділення конкретного житлового приміщення саме як службового, що дає можливість наймачеві знати про свій обов'язок звільнити його після припинення правовідносин із роботодавцем.

У позові про виселення зі службового приміщення зазначається, що особа, яка в ньому проживає, припинила трудові або службові відносини з підприємством, установою, організацією, що є власником цього помешкання або за якою воно закріплене на праві оперативного управління, не має разом із членами своєї сім'ї передбачених ст. 125 ЖК обставин, які унеможливлюють виселення без надання іншого житлового приміщення, та відмовляється його звільнити добровільно. Крім того, у ньому конкретно наводяться суспільні відносини, яким завдається шкода внаслідок незаконного користування службовим житлом особою, яка втратила на це право. Обгрунтування пропорційності обмеження права громадянина на недоторканність житла в результа- 
ті виселення має розкривати неможливість забезпечення захисту зазначених відносин або цінностей іншим шляхом.

Сумнівно, що нагальна суспільна необхідність для виселення відповідачів може бути обгрунтована чергою працівників, які можуть претендувати на заселення в службове житло, як зазначено в п. 66 Постанови ВПВС [1]. Адже, згідно із житловим законодавством України, службове житлове приміщення надається фізичній особі незалежно від іï перебування на квартирному обліку, без урахування пільг, передбачених для забезпечення громадян житлом. Разом із тим наявність конкретних працівників, характер трудових чи службових відносин із роботодавцем яких потребує проживання в зазначеному службовому приміщенні, та їх важливість і необхідність для інтересів підприємства, установи, організації, яким належить службове житло, є вагомим аргументом на підтвердження вказаної суспільної потреби.

\section{Висновки}

3 огляду на рішення ВПВС, підстава для виселення особи зі службового житлового приміщення не обмежується фактом припинення трудових або службових відносин із підприємством, установою, організацією, що є власником житла, а має комплексний характер. Важливими її складниками є елементи, що стосуються дотримання прав наймача, які сучасна судова практика в Україні пов'язує 3 європейськими стандартами та які мають бути чітко відображені в новому Житловому кодексі України для уникнення їх неоднозначного й довільного тлумачення. Положення житлового, цивільного законодавства та Основного Закону України, що регламентують захист житлових прав громадян і їх обмеження, у тому числі внаслідок виселення зі службового житла, потребують приведення у відповідність до положень Конвенції про захист прав людини і основоположних свобод та узгодження між собою.

\section{Список використаних джерел:}

1. Постанова Великої Палати Верховного Суду від 4 липня 2018 року у справі № 653/1096/16ц про визнання осіб такими, що втратили право на проживання у службовій квартирі, їх виселення та зняття з реєстраціï. URL: http://www.reyestr. court.gov.ua/Review/75296538 (дата звернення: 20.04.2019).

2. Житловий кодекс Української РСР: Закон України від 30 червня 1983 р. № 5464-Х. Відомості Верховної Ради УРСР. 1983. Додаток до № 28. Ст. 573.

3. Цивільний кодекс України: Закон України від 16 січня 2003 р. № 435-IV. Відомості Верховної Ради Украӥни. 2003. № 40-44. Ст. 356.

4. Івашова І.П. Володіння як підстава виникнення права користування житлом. Правовий вісник Української академії банківської справи. 2014. № 2 (11). C. 42-45.

5. Кисіль В. Право нерухомості: карколомні судові рішення 2018, частина 1. URL: https://biz.ligazakon.net/ua/news/183332_pravonerukhomost-karkolomn-sudov-rshennya-2018chastina-1 (дата звернення: 20.04.2019).

6. Конвенція про захист прав людини і основоположних свобод від 4 листопада 1950 р. Офіиійний вісник України. 1998. № 13. С. 270.

7. Рішення Європейського суду з прав людини у справі «Коннорз проти Сполученого Королівства» («Connors v. the United Kingdom») від 27 травня 2004 р. (заява № 66746/01). Практика Європейського суду з прав людини. Рішення. Коменmapi. 2004. № 3 .

8. Рішення Європейського суду з прав людини у справі «Кривіцька та Кривіцький проти України» («Kryvitska and Kryvitskyy v. Ukraine») від 2 грудня 2010 р. (заява № 30856/03). Офіиійний вісник України. 2012. № 43. Ст. 150. Ст. 1690.

9. Конституція України: Закон України від 28 червня 1996 р. № 254к/96-ВР. Відомості Верховної Ради України. 1996. № 30. Ст. 141.

10. Case of Karakutsya v. Ukraine. The European Court of Human Rights from 16 February 2017 (Application no. 18986/06). URL: https://hudoc.echr. coe. int/eng\#\{"fulltext":["\"18986/06\""],"documentcollectionid2":["GRANDCHAMBER","CHAMBER"],"itemid":["001-171475"]\} (дата звернення: 20.04.2019).

В статье с учетом позиии Большой Палаты Верховного Суда и вследствие сравнения норм нащионального законодательства Украины и международно-правовых актов раскрываются и анализируются содержание оснований для выселения из служебных жилых помещений, механизм их обоснования, а также формируются предложения относительно законодательного урегулирования правоотношений в этой сфере.

Ключевые слова: служебное жилье, выселение из служебного жилья, основания для выселения, владение недвижимым имуществом, вмешательство в право лица на уважение жилища.

Taking into account the Supreme Court Grand Chamber position and as a result of comparison, there are Ukraine's national legislation and international legal acts ' norms, the grounds 'contents for eviction from office premises, the mechanism of their substantiation are revealed and analyzed in the article as well as proposals for the legal relations regulation of in this sphere are formulated.

Key words: service housing, eviction from service housing, grounds for eviction, possessing of the real estate, interference with a person`s right to respect for the home. 